Article

\title{
Exploring the Gap between Ecosystem Service Research and Management in Development Planning
}

\author{
Nadia Sitas ${ }^{1,2, \dagger, *}$, Heidi E. Prozesky ${ }^{3,4, \dagger}$, Karen J. Esler ${ }^{1,4, \dagger}$ and Belinda Reyers ${ }^{1,2, \dagger}$ \\ 1 Department of Conservation Ecology and Entomology, Stellenbosch University, Private Bag X1, \\ Matieland 7602, South Africa; E-Mails: kje@sun.ac.za (K.J.E.); breyers@csir.co.za (B.R.) \\ 2 Natural Resources and the Environment, Council for Scientific and Industrial Research, \\ PO Box 320, Stellenbosch 3599, South Africa \\ 3 Department of Sociology and Social Anthropology, Stellenbosch University, Private Bag X1, \\ Matieland 7602, South Africa; E-Mail: hep@sun.ac.za \\ 4 Centre for Invasion Biology, Stellenbosch University, Private Bag X1, Matieland 7602, \\ South Africa
}

$\dagger$ These authors contributed equally to this work.

* Author to whom correspondence should be addressed; E-Mail: nsitas@csir.co.za; Tel.: +2721-888-2492; Fax: +2721-888-2473.

Received: 6 February 2014; in revised form: 7 May 2014 / Accepted: 27 May 2014 /

Published: 12 June 2014

\begin{abstract}
The gap between science and practice has been highlighted in a number of scientific disciplines, including the newly developing domain of ecosystem service science, posing a challenge for the sustainable management of ecosystem services for human wellbeing. While methods to explore science-practice gaps are developing, testing and revisions of these methods are still needed so as to identify opportunities for mainstreaming ecosystem service science into development policies and practice. We designed and tested an approach to explore the presence and nature of a research-management gap in order to identify ways to close the gap, using a South African case study. Our combining of traditional review processes with stakeholder interviews highlighted that ecosystem services are not explicitly referred to by the majority of ecosystem management-related documents, processes or individuals. Nevertheless, at the local level, our approach unearthed strategic opportunities for bridging the gap in the tourism, disaster management and conservation sectors. We also highlighted the current trend towards transdisciplinary learning networks seen in the region. While we found a gap between the research and management of ecosystem
\end{abstract}


services, a rigorous study thereof, which transcends its mere identification, proved useful in identifying key opportunities and challenges for bridging the gap.

Keywords: land-use planning; ecosystem management; communication divide; mainstreaming; multi-stakeholder engagement; sustainable development

\section{Introduction}

The need to develop sustainably on a finite planet has become increasingly evident $[1,2]$. Sustainable development requires multi-scale policies, plans and decision-making that acknowledge the importance of meeting current and future human needs without undermining the resilience of natural systems and the environment. In the past decade, we have seen significant advances in our understanding of the social and biophysical aspects that determine the state and dynamics of social-ecological systems [3-5]. However, the translation of this knowledge into actionable strategies, designed to inform management and policy and enhance equitable sustainable development and environmental stewardship, is limited [6-9].

The emergence and expansion of "ecosystem service science", popularized by the Millennium Ecosystem Assessment (MA), builds towards a knowledge base of the complex interconnectedness between humans and the services nature provides [10]. This research area emphasizes the importance of sustaining specific flows of ecosystem services to ensure that human development goals are met and, therefore, has the potential to have a large impact on the management of ecosystems and resulting benefit flows. While there has been rapid and widespread adoption of ecosystem service-based frameworks in policy and practice, both ethical [11,12] and operational [13] challenges with the concept of ecosystem services remain, particularly in the developing country context [14]. This signals the need to better understand ecosystem services as a contested concept [15], especially as it relates to the design and implementation of strategies aimed to promote human wellbeing. However, while the term and its implementation are contested, the notion of the benefits societies and economies get from nature is not [3], and so, we move to explore the concept of the benefits, rather than the term itself.

Mainstreaming of ecosystem services requires effective knowledge exchange processes between diverse sets of stakeholders that enable the science of ecosystem services to be operationalized on the ground $[16,17]$. While the science of ecosystem services is rapidly advancing, the knowledge of how decision-makers and decision-making processes at local levels are using and implementing the science remains scarce. Understanding the current use and uptake of the concept, especially as it relates to current planning processes, is pivotal for effective implementation.

There has been a concerted research effort over the last few years to better understand "knowing-doing gaps" [12] in social-ecological research [16]. In the past, confirmation of the gap between science and practice was mainly achieved by assessing trends in the published literature, citation counts and/or author intent or by providing a theoretical overview of debates around "knowing versus doing" (see Esler et al. [18] and Lauber [19]). Cash et al. [20] have suggested that in order for knowledge to be taken up into decision-making processes, it needs to be credible, salient and legitimate. Thus, research is now moving towards engaging with implementers or managers as 
key actors in the research-management divide [21-24]. Here, transdisciplinary research, which acknowledges the importance of a plurality of perspectives and transcends disciplinary boundaries, holds much promise [25].

While there are increasingly applications of the ecosystem services framework in practice, the majority focus on payment-based schemes and have not yet surfaced in the published peer reviewed literature [26-28]. Therefore, evidence from studies of how to operationalize ecosystem services within other contexts and in developing countries is still needed. Attempts at understanding how to translate ecosystem science into practice is complicated by issues concerning information availability and accessibility (e.g., published versus grey literature and other knowledge sources) and confusion about specific disciplinary-based terms, for example "ecosystem service". That is, implementers may be working in the realm of ecosystem services, e.g., water or land management, yet do not use the term "ecosystem service" explicitly in relation to their work.

Thus, our objective of exploring how the concept of ecosystem services manifests in ecosystem management and policy, linked to development planning, requires a flexible method that extends beyond a literature review and/or a reliance on bibliometric methods, which would only highlight the uptake of a specific scientific term. We focus on development planning, a process that identifies the role that different sectors of society need to play in order to improve human wellbeing, by addressing social, economic and environmental issues in an integrated manner [29,30]. In South Africa, much like other developing countries, development trajectories are based on the National Development Plan, which outlines sector-specific goals to reducing poverty and plans for mechanisms to tackle cross-cutting issues that impact South Africa's long-term development [31].

As the conservation of ecosystem services is ultimately a social process operating in a social context, we support other research that has shown that understanding the complexity of the research-management interface demands input from a range of stakeholders [32-35]. Accordingly, methods should investigate the experiences of potential implementers of ecosystem service research. To identify the way in which ecosystem services are identified and expressed in or, indeed, omitted from management and policy linked to development planning, we developed and trialed a method that involves engaging with multi-sectoral decision-makers and their associated decision support tools. We specifically aimed to explore: (1) whether the concept of ecosystem services does or does not manifest in ecosystem-management processes; and (2) how the concept of ecosystem services is being used in these processes.

Consequently, we use a case study at the local level in South Africa to better understand the realities of integrating information in the development planning process, which in South Africa is specifically geared toward addressing the injustices of the apartheid era planning and taking into account the socio-economic needs of local communities through sustainable service delivery.

In the context of this study, management refers to purposeful activities (e.g., planning and implementation), which affect ecosystems and their resources, which include processes that range widely from conservation to disaster management. Our definition of "process" is a systematic series of management actions, which include relevant policy and decision support tools (i.e., any resource that aids in the decision-making process and that may range from documents, plans and maps to computer-based systems). We define ecosystem services in line with the MA definition, as referring to the benefits people obtain from ecosystems [8]. 


\section{Methods}

Using a case study research design [36], we developed a two-phase review framework, which guided a content analysis of available decision support tools identified by practitioners to be important for development planning and of transcriptions of semi-structured interviews with decision-makers at the municipal level.

\subsection{A Focus on the Local Level}

In South Africa, the government system is formally comprised of three spheres: national, provincial and local. There are nine provincial governments in South Africa, and the country is divided into local municipalities, of which there are three types: metropolitan (in the six biggest cities of South Africa), local (areas that fall outside the six metropolitan municipal areas) and district (an aggregation of local municipalities that fall within one district). The Municipal Systems Act No. 32 of 2000 charges local government with a variety of roles and responsibilities, such as regulatory functions associated with the approval of new developments and any modifications to the landscape and built environment. Local municipalities contribute towards enforcing statutory regulations on behalf of other spheres of government and play a strong role in the provision of public services, such as promoting local tourism, electricity delivery, sanitation and sewerage, storm-water and disaster management and recreation facilities. Local government is the sphere of government closest to the scale at which ecosystem management activities and decisions take place. Accordingly, it provides a suitable focus for our research on current ecosystem management processes and how these relate to future sustainable development in the region.

\subsection{Study Site}

The Eden District (Eden) is located in the southern Cape region of South Africa and comprises a district municipality encompassing seven local municipalities (Figure 1). Eden occupies an area of $23,321 \mathrm{~km}^{2}$ and more than $300 \mathrm{~km}$ of Indian Ocean coastline [37].

The municipality is characterized by the "Garden Route", a stretch of scenic coastline popular with tourists, developers and job seekers. A brief summary of the demographics of Eden can be found in Table 1. Complex social-ecological challenges exist in Eden, highlight the need for a targeted approach for reconciling ecosystem services with future development trajectories and render Eden a suitable case for this research (see Sitas et al. [14] for an overview of the challenges). Eden has a long history of ecosystem service research with numerous scientific and academic research institutions conducting research on ecosystem services there, including the South African Millennium Ecosystem Assessment (SAfMA) and the Succulent Karoo Ecosystem Partnership (SKEP) [38-43]. A variety of landscape initiatives provide important opportunities for multi-stakeholder engagement, such as the Garden Route Initiative (GRI), Cape Action for People and the Environment (CAPE), the Subtropical Thicket Ecosystem Project (STEP) and the newly formed, Gouritz Cluster Biodiversity Reserve Forum (GCBR). 
Figure 1. Map of the Eden District showing its location in South Africa and highlighting the Eden District municipal boundary and seven local municipalities: (A) Hessequa; (B) Kannaland; (C) Mossel Bay; (D) Oudtshoorn; (E) George; (F) Knysna; (G) Bitou and major towns.

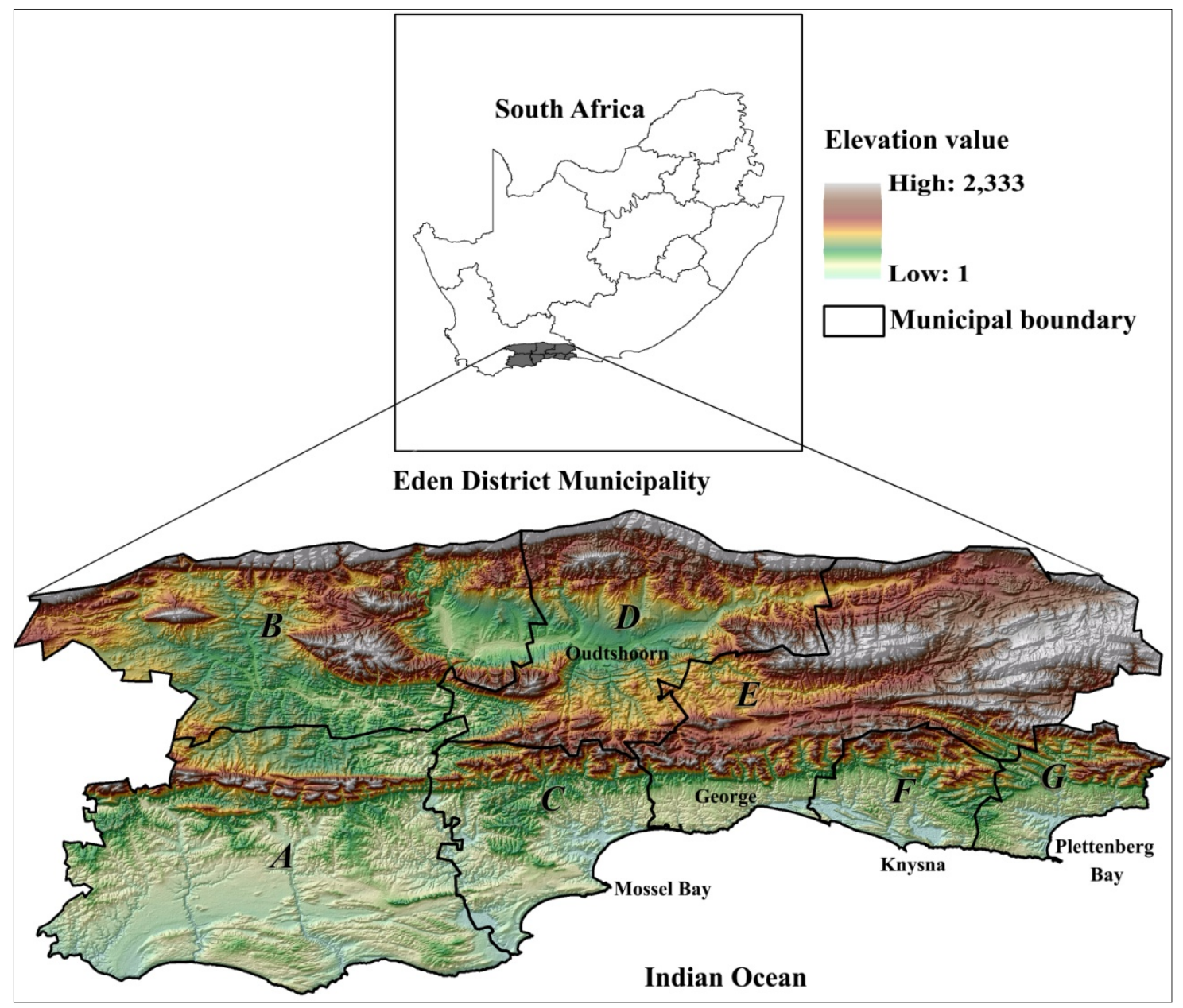

\subsection{Data Collection}

The first phase of our research commenced with the identification of key processes, documents and individuals involved in ecosystem management, through an iterative process guided by a focused review, expert and practitioner opinion and other sources, such as municipal websites.

\subsubsection{Interviews}

To develop an in-depth understanding of the realities experienced by implementers, interviews were conducted with municipal officials in Eden, i.e., individuals employed by local municipalities to provide technical assessments and other inputs that inform development and management processes. Respondents were purposively selected at both the local and district levels from key departments involved in or affected by decisions related to ecosystem management [44]. Nine municipal officials were interviewed, representing departments related to planning and development, environmental management, disaster management and technical services (the department of technical services deals with issues related to electro-technical services, streets and storm water, water and sewerage, sports 
and recreation and cleansing services). The face-to-face interviews were exploratory and semi-structured in nature. Initial questions collected background data on respondents (e.g., educational background, job priorities, etc.), and subsequent questions concerned the use of key planning documents and processes, knowledge integration and information sharing, collaboration and environmental decision-making.

Table 1. Table showing the biophysical and socio-economic information of the Eden District Municipality and associated local municipalities, namely Bitou, George, Hessequa, Kannaland, Knysna, Mossel Bay and Oudtshoorn.

\begin{tabular}{cccccccl}
\hline Municipality & $\begin{array}{c}\text { Area in } \\
\mathbf{k m} \mathbf{2}^{2}\end{array}$ & $\begin{array}{c}\text { Areas } \\
\text { remaining } \\
\text { natural (\%) }\end{array}$ & $\begin{array}{c}\text { Population } \\
\mathbf{2 0 1 1}\end{array}$ & $\begin{array}{c}\text { Population } \\
\text { growth } \\
\mathbf{( \% ) . a . )}\end{array}$ & $\begin{array}{c}\text { Poverty } \\
\text { index } *\end{array}$ & $\begin{array}{c}\text { \% no } \\
\text { income }\end{array}$ & $\begin{array}{c}\text { Main economic } \\
\text { development thrust [45] }\end{array}$ \\
\hline Bitou & 992 & 75 & 49,162 & 5.2 & 20.7 & 25.5 & Tourism, retirement \\
\hline George & 5241 & 62 & 193,672 & 2.6 & 19.6 & 38.1 & $\begin{array}{l}\text { Broad-based services, manufacturing } \\
\text { and trade, tourism, agriculture }\end{array}$ \\
\hline Hessequa & 5729 & 51 & 52,642 & 1.8 & 17.5 & 33.4 & Agriculture, tourism, retirement \\
\hline Kannaland & 4755 & 76 & 24,767 & 0.3 & 21.7 & 30.6 & Agriculture, tourism \\
\hline Knysna & 1059 & 56 & 68,659 & 2.8 & 22.2 & 33.7 & Agriculture, tourism, retirement \\
\hline Mossel Bay & 2010 & 61 & 89,430 & 2.2 & 16.5 & 40.6 & Harbor, manufacturing, trade and tourism \\
\hline Oudtshoorn & 3535 & 66 & 95,933 & 1.3 & 19.1 & 40.8 & Agriculture, tourism and agriprocessing \\
\hline Eden & 23,321 & 64 & 574,265 & 2.3 & 21.0 & 33.1 & Well diversified \\
\hline
\end{tabular}

* The Poverty Index for the Western Cape was developed by the Department of Social Development in the Western Cape using 10 indicators. The higher the poverty index score, the higher the level of poverty [46].

\subsubsection{Documents}

A preliminary review of legislative documents at both the national and local level showed no explicit reference to ecosystem services, and thus, we only focused on those documents that, according to practitioners, influence how land, water, resources, facilities and services are allocated within municipalities [47]. Development and land-use planning in South Africa is regulated through the Municipal Systems Act 32 of 2000, which places the main responsibility for planning on municipalities through a compulsory process of Integrated Development Planning (IDP). The resulting plans are then expressed spatially in the form of a Spatial Development Framework (SDF) [48]; therefore, these two planning instruments were core to this analysis. In addition, we analyzed a suite of documents, including the Biodiversity Sector Plans for the region, designed by independent consultants to assist planning in accordance with the National Environmental Management: Biodiversity Act (NEMBA) Act 10 of 2004, which are currently the main environmental informants for local development planning. We also reviewed available municipal budget allocations for similar periods to see how much of the yearly budget was spent on ecosystem-related activities (e.g., those activities relating to environmental protection or restoration activities).

The final 46 documents selected for analysis reflect the key documents and processes that contribute, at least in theory and according to legislation, to ecosystem management (for example, conservation and land-use planning regulations) and, importantly, were identified on the basis of practitioner opinion and expert advice (Table 2). 
Table 2. Summary of decision support tools reviewed, including the municipal scale of the document, type of document and number reviewed $(n=46)$.

\begin{tabular}{clc}
\hline Scale & \multicolumn{1}{c}{ Type of Document } & Total Number \\
\hline Local & Water Services Development Plan & 7 \\
Local & Local Economic Development Plan & 6 \\
District & Growth and Development Strategy & 1 \\
District & Integrated Waste Management Plan & 1 \\
District & State of the Environment Report & 1 \\
Mixed & Integrated Development Plan & 8 \\
Mixed & Spatial Development Framework & 8 \\
Mixed & Disaster Management Plan & 3 \\
Mixed & Municipal budget & 8 \\
Regional & Biodiversity Sector Plans & 3 \\
\hline Total & & 46 \\
\hline
\end{tabular}

All planning tools used to guide decision-making in Eden are in the public domain and were obtained from the Eden District Municipality website or from key personnel in the relevant departments within municipalities. The most recent versions of planning tools were selected in preference to older ones, and the majority of documents postdate ecosystem service research interactions between research institutions/researchers and municipalities, with no document dated earlier than 2005. Each planning tool was reviewed and analyzed against the framework we developed (Figure 2).

\subsection{Data Analysis}

During the second phase of our research, we developed and applied an assessment framework (Figure 2) to guide a content analysis of tools and interview responses, in order to identify: (1) the extent to which the concept of ecosystem services was referred to either explicitly (using terms consistent with our definition of ecosystem service), implicitly (through terms roughly synonymous with those associated with our definition of ecosystem services) or not at all; and (2) where ecosystem services had been integrated, to assess which services were mentioned, where and how. We did not apply the review framework to our analysis of the municipal budgets as these are not descriptive documents, but instead, we reviewed whether any of the budget was allocated to ecosystem related activities. Consequently, we report on these documents separately in our results.

The assessment framework (Figure 2) recognizes that the concept of "ecosystem services" includes the values, processes, benefits or services derived from nature, and therefore, both the manifest (explicit) and latent (implicit) content of ecosystem services were coded [49]. Explicit reference to ecosystem services was whether ecosystem services were explicitly identified using the terms of the MA (e.g., food, genetic resources, etc.). An implicit reference to an "ecosystem service" was where the services can be inferred from the words used, e.g., "moderates temperature", which is synonymous with climate regulation, or "ecological buffer" with natural hazard regulation. The distinction between an explicit or implicit reference was made specifically to consider the degree to which the language of ecosystem service science has been taken up in the management of ecosystems. While the concept of ecosystem services (i.e., the benefits humans receive from nature) already gained popularity in the 
1940s [50]; only in the last 10 years has the term only become widely used [51], especially following the MA conducted in the period 2000-2005. In cases where ecosystem services were included (explicitly and implicitly), we determined the MA category to which they belong (namely cultural, provisioning, regulating and supporting) and the depth of knowledge associated with the concept of ecosystem services. Knowledge was categorized as comprehensive if: (1) reference was made to all four MA categories of ecosystem services; (2) examples of specific ecosystem services were provided; (3) links were made between ecological processes/functions and the end benefits humans receive; and (4) information/data on ecosystem services, e.g., a map or economic valuation, was included or alluded to. If three of four of the criteria were not met, the information was categorized as "basic". Initially, we had a third category of "intermediate"; however, we found that none of the plans fell in this category.

Figure 2. Assessment framework based on Egoh et al. [52] and Haines-Young and Potschin [53], which was used to guide the content analysis of decision support tools and interview data.

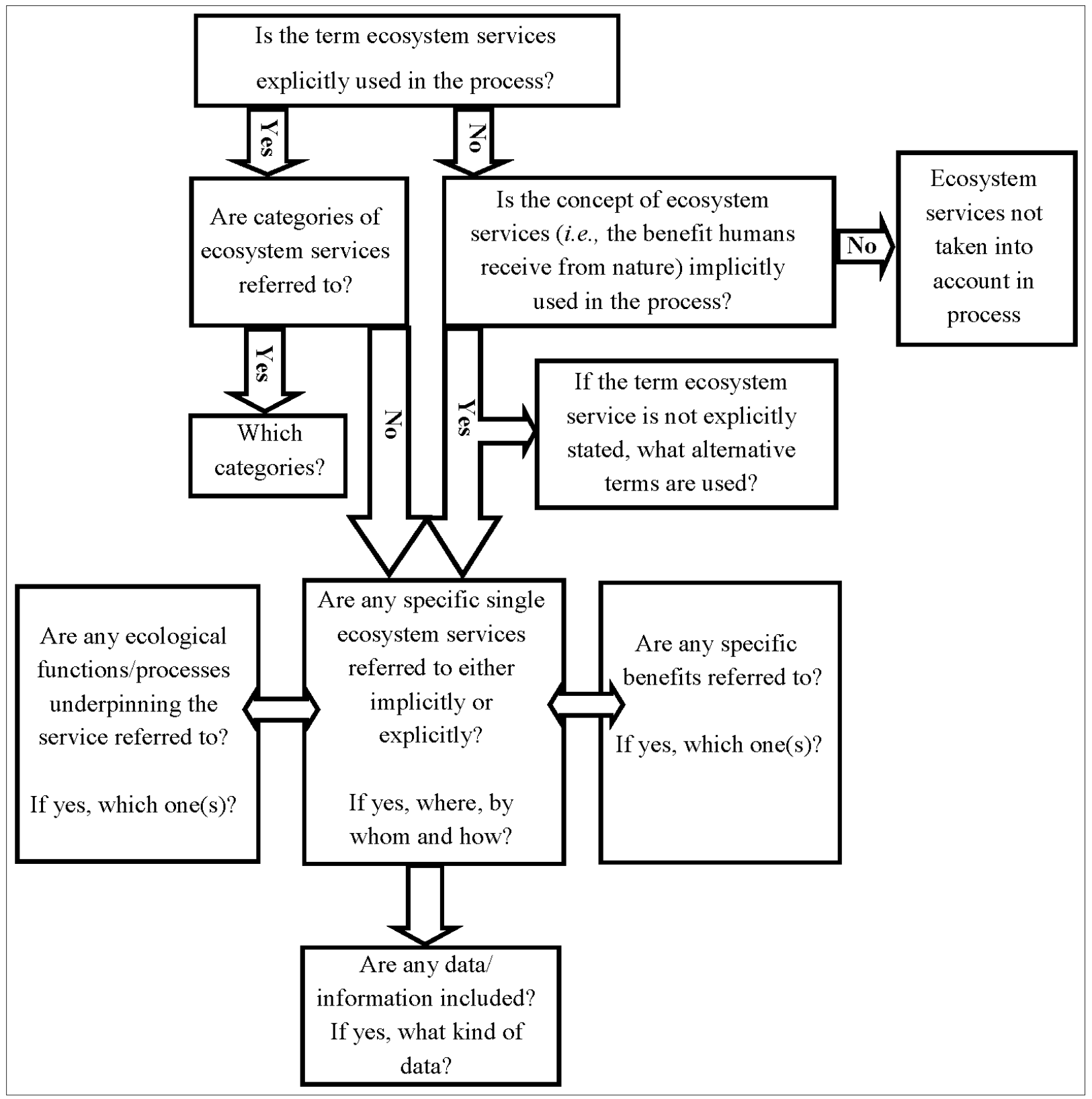


Selecting an ecosystem services framework upon which to guide our analysis was hard, as there are strengths and weaknesses to most proposed frameworks [54]. We used the frameworks suggested by Egoh et al. [52] and Haines-Young and Potschin [53] to develop our review framework, as they cite human needs at the center of ecosystem management and are not explicitly focused on assigning monetary valuation to ecosystem services. In acknowledging that services do not exist in isolation from human needs, important links to the goal of development planning (i.e., improvement of human wellbeing through sustainable development) could be made. The Haines-Young and Potschin [53] framework was especially key in that it acknowledged "ends" with "means" and linked the two ends of a production chain. These frameworks were also used, as they allow one to recognize the implicit inference of the concept of ecosystem services, i.e., not just the end services, but the ecological structures and processes that are important for producing the "benefits" that humans derive from ecosystems.

\section{Results}

\subsection{Document Analysis}

Ecosystem services were explicitly and comprehensively referred to in only four (11\%) documents, three of which were regional biodiversity sector plans, with the reference to ecosystem services occurring in various sections of the documents, including introductory chapters, context specific examples and integrated into management guidelines. Five documents (13\%) referred explicitly to ecosystem services, but the inclusion was considered basic according to our criteria and mention of ecosystem services was restricted to introductory paragraphs and/or environmental sections only and not linked to specific management guidelines or ecosystem management related activities, e.g., restoration. Of the documents reviewed, $8 \%$ made no reference at all to ecosystem services, while the remaining 63\% included only an implicit and basic reference to one or more ecosystem services (Figure 3), and the reference to ecosystem services was mostly only associated with describing the beauty of the region and not integrated into any specific guidelines, action plans or priority projects.

Figure 3. Frequency of decision support tools that make either explicit, implicit, or no reference to the term, ecosystem service, and the extent to which the information is comprehensive or basic $(n=38)$.

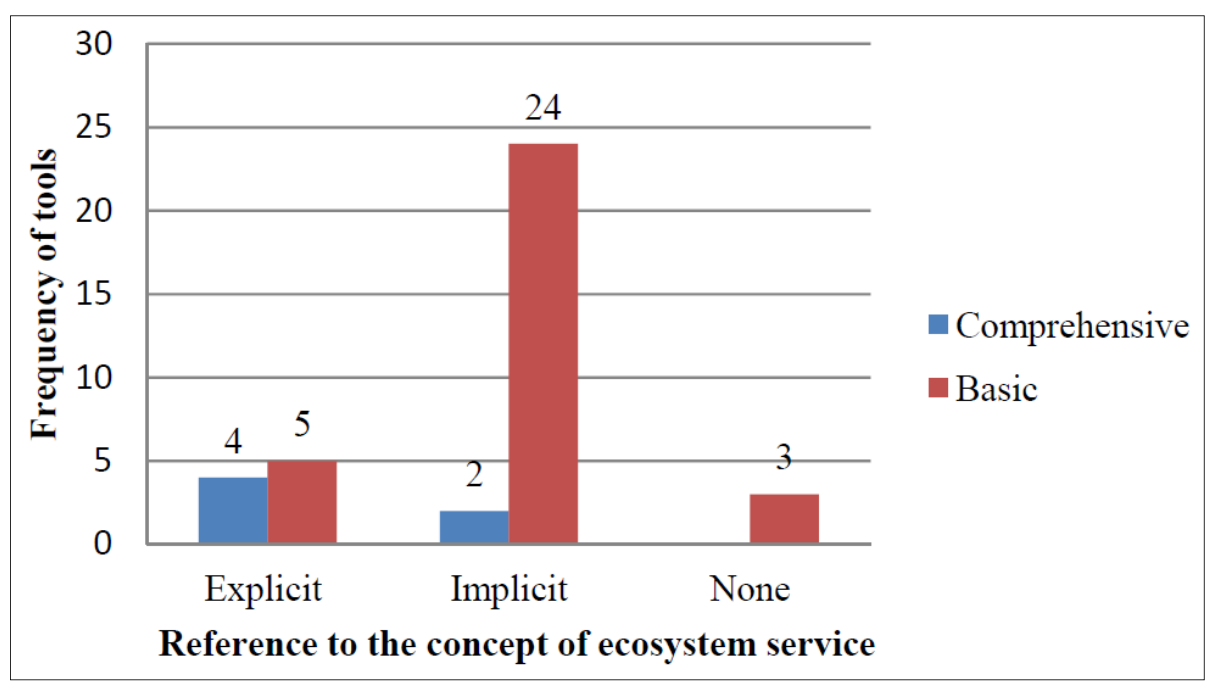


All four broad categories of ecosystem services (provisioning, supporting, regulating and cultural) were referred to either implicitly or explicitly (Figure 4). Of those mentioned, the cultural benefits of tourism and recreation featured most often (76\%), followed by ecosystem services directly linked to food (63\%), fresh water (61\%) and natural hazard regulation (58\%) (Figure 4).

Figure 4. Frequency of explicit and implicit references to ecosystem services occurring within decision support tools $(\mathrm{n}=38)$.

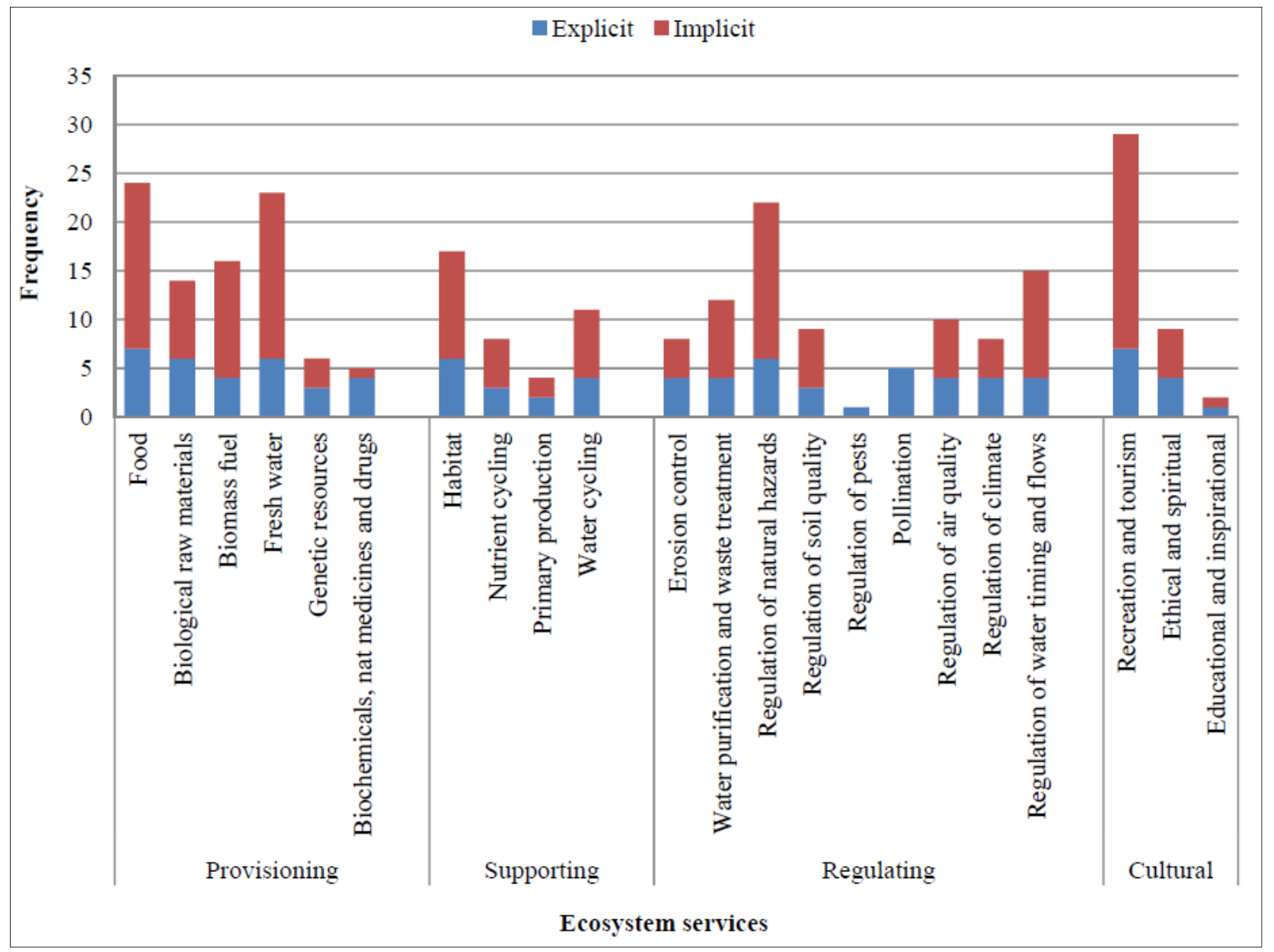

In the documents analyzed, the importance of ecosystems for human benefit was often mentioned, especially in relation to local economic development. Phrases, such as "goldmine above the ground", "exceptional beauty", "pristine nature" and "green gold", of the region were used to describe how ecosystems contribute to the tourism sector and, more broadly, how "the natural environment sustains the economy through eco-tourism, agriculture and forestry" and "nature is the backbone of our economy". Other frequently used terms related to how ecosystems provide "ecological buffers" or "storm protection" against extreme events; however, it is notable that such terms did not appear in local-level disaster-management plans. Synonyms for ecosystem service were used, such as natural capital, environmental services and nature's benefits, services, wealth and value, but often, the reference was less explicit and had to be inferred and was found in the preambles of the documents (e.g., introductory paragraphs) linked to concepts of sustainability, but not in the operational or planning sections.

District or regional-level documents (e.g., biodiversity-sector plans encompassing more than one local municipality) referred to ecosystem services more comprehensively and explicitly than plans 
developed at a local municipal level. In addition, documents related to the biodiversity and environmental sectors (e.g., State of Environment reporting, which is a process carried out at various levels, such as the municipal or national scale, and is designed to provide information to the public, industry, non-government organizations and all levels of government to inform multi-sectoral decisions, which influence or are influenced by the environment) also provided more comprehensive references to ecosystem services, linking ecosystem services to the processes/functions from which they flow. In comparison, those related to water or waste focused more on built infrastructure and public services.

Only three municipalities allocated money towards ecosystem related activities linked to "environmental protection", "environmental management" and "protected areas"; however, none of these amounts were greater than $1 \%$ of the total operating budget, and no further details were provided about the activities.

\subsection{Analysis of Interview Data}

While seeking out potential respondents, we found that none of the eight municipalities in Eden have environmental departments or divisions, and only three of the eight have a dedicated environmental officer, located either within development and/or town-planning departments or in the community-services directorate as part of "parks and recreation". Two municipalities employed officials mandated to deal with "environment-related work" as part of a mixed portfolio, and three municipalities lacked a person responsible for environmental issues. The age of the respondents ranged from 25 to 60 years, and all but one of the respondents had been involved in municipal planning for over 10 years. The educational backgrounds of the respondents varied from engineering, town/urban/regional planning, environmental management, military training, environmental and geographical science and urban infrastructure management and design.

During the interviews, none of the officials explicitly made reference to ecosystem services, and when the subject was raised at the end of the interview, only three of the nine officials were familiar with the specific term "ecosystem service". However, only one could provide a definition similar to ours, linking ecosystem services mainly to economic value and incentives (e.g., enforcing mining companies' payments for ecosystem services damaged due to mining operations and promoting recreational hunting), while the other two respondents confused ecosystem services with public service delivery, i.e., the provision of services and infrastructure necessary to meet the basic needs of communities, e.g., electricity, sanitation and water. Implicitly, however, a number of officials (none of them with a background in environmental management) did refer to the concept of ecosystem services. Three officials linked the natural resource base to tourism opportunities and local economic development. For example, one stated: "The Western Cape, that [nature] is our gold —we don't want to take the garden out of the Garden Route", while another warned that development should not "kill the goose that lays the golden egg".

Three officials referred to the benefit of clean drinking water in relation to drought and municipal service delivery, with one of those three officials highlighting the need for better management of catchments to ensure water quality, especially in the context of flood damage of waste-water-treatment works. Three officials made implicit reference to the importance of enhancing the disaster-regulation capacity of systems; all three referred to flood regulation: one official linking it to the "hazard 
absorbing capability" of wetlands and the other two officials mentioning coastal erosion. Although not specific to ecosystem services, four officials spoke about the importance of biodiversity and how it benefits Eden, with one official stating, "Our biological heritage is so important to us in many ways". All respondents were aware of the biodiversity-sector plans and legislation pertaining to the consideration of biodiversity in municipal planning. However, only three of the respondents mentioned that biodiversity data actively inform their recommendations.

Our engagement with people working within the environmental and/or disaster management sectors revealed that they spoke more about ecosystem services (albeit implicitly) than people working on issues related to built infrastructure or town planning. Most of the "environmental" issues raised by the latter tended to relate more to legislation and regulatory systems than specific ecosystem considerations. Similar to what emerged from the document review, we found scale to be important, as officials working at a district level seemed to have a broader understanding of the benefits that ecosystems provide and how they should be accounted for in management processes.

\section{Discussion}

Our study presents a snapshot of the gap between ecosystem service research and the management of those services at the local level in South Africa. It demonstrates that, even for a region with a history of ecosystem service research and multi-stakeholder engagement between scientists, landscape initiatives, municipalities and governmental and non-governmental organizations, there still appears to be a gap between research and management. The extent of the gap differs across scales and sectors and between what is written and what is known. Below, we discuss our results and present some future research opportunities based on these findings.

\subsection{Exploring the Gap}

The method outlined and tested in this paper provides a nuanced understanding of the gap between ecosystem service research and management at a local level. We found substantial differences in the understanding of the concept of ecosystem service across sectors, which we have not seen elsewhere. By identifying both explicit and implicit mentioning of ecosystem services, we moved beyond searching for the uptake of a specific scientific term, which can often take time to enter into the operational language of both practitioners and planning documents [55], to how a concept may manifest more implicitly.

Our analysis shows that particular links between ecosystems and the benefits they provide are recognized by certain ecosystem management processes and respondents, i.e., those focusing on services fundamental for human survival (food, water and security) and those contributing to the local economy (tourism). However, few management processes (outside of the conservation sector) provided information on how ecosystem integrity can be maintained, other than referring to sustainable development and acknowledging that development options should not impact negatively on nature. Despite the emphasis on sustainable development through ecosystem management processes, the region is experiencing rapid urban development at the expense of natural ecosystems [37], signaling that what is stated in ecosystem management processes, does not necessarily reflect what is happening on the ground. 
Accordingly, ecosystem services were best represented in the biodiversity sector plans and mentioned by those individuals more familiar with the biodiversity sector (i.e., environmental and district-level-planning officials). This is perhaps due to several factors, including the strength of the biodiversity planning sector and its often dominant engagement in land use and other planning processes [56], as well as the long history of conservation planning and engagement in this region [57,58]. As biodiversity underpins a variety of ecosystem services [10] and ecosystem services can help make the case for biodiversity conservation [59], the biodiversity sector has been aware and engaged with these concepts for perhaps the longest. Further, the majority of respondents involved in biodiversity or conservation-related activities hold tertiary qualifications related to the environmental sciences (e.g., ecology or botany).

While this uptake by the well-capacitated biodiversity sector is positive, for ecosystem services to truly inform development planning, there is a need to move into more powerful sectors of decision-making, e.g., water management, mining, land use planning, which often take precedence over biodiversity sector inputs [56]. In this regard, it is promising to note that ecosystem services were referred to in numerous documents in relation to disaster management. Disaster management is often better resourced and higher up the sectoral hierarchy of decision-making; however, at the same time, two of the three decision support tools that made no reference to ecosystem services were local municipality disaster management plans. Increasingly, healthy ecosystems are recognized globally by scientists as essential for providing services for disaster management $[4,60,61]$. While they may be recognized in higher level planning documents, the failure of these decision tools to make room for ecosystem services highlights the need for intervention strategies that enable ecosystem-based risk-reduction initiatives [62]. The opportunities for this appear good, as the results show that the officials involved in disaster management were among the best informed in terms of the role of regulating services in risk management. Thus, the co-development, by researchers and disaster managers of tools and frameworks that mainstream data and approaches for regulating ecosystem services into disaster-management appear to offer possible future directions.

\subsection{Operational Challenges}

Despite the potential benefits that an ecosystem service - based approach holds in theory, numerous debates continue in the literature around its potential legitimacy, risks and benefits [11,13,63-66]. We found that without addressing some of these shortcomings, it will be difficult to move the science of ecosystem services into practice at a local level.

\subsubsection{Capacity}

It became apparent across all local municipalities in our study site that capacity and resources were insufficient to carry out ecosystem management activities, especially in terms of conducting research and compiling information on the current status and trends of ecosystem services in the region and for drafting appropriate management action plans. Although all municipalities are mandated to implement sustainable development activities, currently, local authorities are not bound by any specific national legislation for employing municipal officials to oversee environmental management, nor is there any national standard that relates to the requirements for appointing environmental management officials. 
There are requirements to have officials who are involved with air quality and waste management, which are often seen as environmental management, but the prevailing perception is that environmental conservation is not a municipal function and should therefore be left to the conservation sector [14].

The vast majority of decision support systems we included in our analysis were compiled by independent consultants and exhibited a large variance in terms of quality and content, rendering it difficult to align ecosystem management objectives across municipal boundaries. As consultancies are hired through independent tender processes to compile specific decision support systems, it was difficult to determine the individual capacities of each of the consultants that compiled the reports as a team and what the terms of reference for the outputs specified. Opportunities exist here for integrating the concept of ecosystem services into the terms of reference of these decision support systems, which would require consultants to work across sectoral and disciplinary boundaries in order to accommodate ecosystem service information into these land-use planning processes. Having ecosystem service consideration explicitly stated in the terms of reference for developing decision support tools would also assist with the review process of these documents by establishing review criteria at a provincial and sector level.

There is clearly a need to strengthen capacity, fill vacancies and support skills development in Eden. However, many traditional approaches often fail, due to a variety of causes, such as high staff turnover, party politics [67] and corruption [68]. Thus, there is a need for the development of new ways of boosting capacity and competency in Eden, which builds on existing strength, capacities and, importantly, mutual interest. Novel partnerships between business, researchers, civil society and local government are currently being forged in Eden in the form of "Business Adopt a Municipality", whereby a business plays a strong role in providing municipalities with resources to improve social-ecological governance [69]. Building on existing toolkits and training developed for mandatory local climate change adaption and mitigation provides additional opportunities for developing local level capacities and capabilities for improved ecosystem management [70].

The capacity of researchers also needs to be improved in terms of communicating their research in ways that resonate best with their intended audience(s), which requires careful consideration of the language frames and fora to be used. A unique level of cooperation and collaboration is needed among policy, implementation, public, scientific communities and combinations thereof, to act on the combined threats facing ecosystem service delivery [71].

\subsubsection{Tools}

A large range of "tools" and heuristics exist in support of an ecosystem service-based approaches, including maps, databases, conceptual frameworks, valuation methods and computer programs (e.g., see $[10,29,54,72-74])$. However, while many of the tools can be extremely useful from an advocacy standpoint, few tools incorporate the kind of information necessary (which is also often absent) to make meaningful recommendations for local-level ecosystem-management activities geared for implementation. According to Primmer and Furman [75], the mismatch between ecosystem management needs and ecosystem service approaches can be addressed only if tools build on existing knowledge systems and governance arrangements and aim at communicating across ecosystem and sector boundaries within specific social, economic and institutional contexts. This is especially important 
given the pressure municipal officials are under to provide basic public services with limited resources and capacity [14]. Many municipalities are currently struggling to achieve their developmental mandate [67]; therefore, unless links are established between ecosystem services and municipal service delivery, the mainstreaming of ecosystem services will remain a comparatively low municipal priority.

Tools that strengthen the evidence of how ecosystem services specifically contribute to different aspects of human wellbeing, with a focus on major sectors in the region (e.g., tourism, agriculture and disaster management), could provide an effective vehicle for engaging with decision-makers in the region [42,54]. This would facilitate acknowledgement of and proactive planning for the protection of key ecosystems and presents a strategic opportunity for promoting more socially relevant ecosystem-service research. However, decision support tools that deal with inter-sectoral, dynamic ecosystem services are scarce. New multi-sectoral networks to explore risk management within the context of climate change are emerging between Eden municipalities, provincial government, business, researchers and civil society and are helping to identify informational needs and integrate available data in existing decision support tools. Here, local level climate change adaptation offers new research avenues and tools that can be built upon.

\subsection{Opportunities for Bridging the Gap}

While acknowledging the challenges for integrating an ecosystem service-based approach for ecosystem management, our engagement with ecosystem management processes in Eden did enable us to identify some key opportunities for integrating information on ecosystem services.

\subsubsection{Transdisciplinary Approach}

The sustainable management of ecosystem services requires cross-sectoral engagement that moves beyond the conservation sector; however, this requires careful navigation across discipline-entrenched thinking. A transdisciplinary approach, which views practitioners as active and equal participants in defining the problem and research agenda, can ensure that research outputs are sufficiently user-inspired and user-appropriate for tackling the specific social-ecological problem at hand [56]. Further, following a transdisciplinary approach can assist with the on-going mainstreaming of certain concepts (e.g., ecosystem services), as all affected stakeholders should be included in the decision-making/research process. Thus, less effort and resources would need to be invested into gaining stakeholder buy-in and the uptake of a resulting product, thereby minimizing the strain on municipalities' already limited capacity and resources. While there are still considerable challenges with undertaking a transdisciplinary approach [76], there are numerous opportunities for conducting transdisciplinary research in South Africa, especially in light of new initiatives, such as the Southern African Programme on Ecosystem Change and Society [77] and the Transdisciplinary, Sustainability, Analysis, Modelling and Assessment Hub [78], which promote, use and share transdisciplinary approaches for addressing complex social-ecological problems. For a transdisciplinary approach to work, issues related to power, participation and politics need to be addressed [79], which is especially challenging in South Africa, given the history and the need to address the lingering legacy of apartheid planning [80]. Such complex challenges require extensive resources, facilitation expertise and time, which few local governments have. Yet, some pilot projects are emerging within the South African 
context, such as The Project for Ecosystem Services [81], Africa's Search for Sound Economic Strategies (ASSET) Research [82] and The Food and Energy, Water, Land, Environment Nexus project [83], which could provide excellent learning opportunities upon which to build.

\subsubsection{Language}

The assumption that various stakeholders, e.g., governmental/municipal agencies, businesses and the public, easily grasp what experts or scientists may consider to be rudimentary concepts or relationships can create barriers to defining common problems When engaging with stakeholders, researchers should be more aware of how they present their results and take note of the terminology they use. Knowledge is highly context-specific, as is the way in which humans think about, name and manage resources. Through these practices, but particularly through language, shared versions of knowledge are constructed [84]. By exploring stakeholders' perceptions of ecosystems and associated benefits in their own terms, it may be possible to unearth opportunities for translating the science of ecosystem services into more user-useful contexts, especially for undertaking research with a strong implementation focus. Raymond et al. [85] provide some useful suggestions on the role that multiple metaphors can play in communicating human-environment relationships, which address some of the ethical concerns related to ecosystem service framings raised by Luck et al. [12]. Multiple metaphors are especially important for communicating the concept of ecosystem services to a wider society and how to establish awareness of the role of ecosystems in sustaining life. Based on our interactions, we suggest that framing ecosystem services in line with current development priorities of the region, for example as contributing to risk management (e.g., flood mitigation), poverty alleviation (e.g., tourism growth) and public service delivery (e.g., water quality), could serve as potential strategies or entry points to enhance the societal relevance of ecosystem service research. By stressing the importance of ecosystem services for municipal service delivery (e.g., the provision of clean water), municipal officials would not have to decide between investing resources in one or the other.

\subsubsection{Biodiversity-Sector Plans}

As all land-use planning decisions are legally mandated to adhere to policy (NEMBA Act 10 of 2004), strengthening the representation and acknowledgement of ecosystem services within biodiversity-sector plans at appropriate scales can provide important opportunities for safeguarding those processes necessary for delivering essential services in the region. However, debates associated with the relationship between biodiversity and ecosystem services caution one to carefully consider how particular ecosystem services trade-off against biodiversity (e.g., natural vegetation vs. agricultural land) [59]. It is therefore important that future research explores the evidence base of the assumption that critical biodiversity areas and/or ecological support areas overlap with ecosystem services [86], thereby assisting in rendering ecosystem services trade-off more explicit for decision-making. Further, enhancing the utility of biodiversity sector plans in land-use planning processes through, for example, the establishment of bioregional plans, could give ecosystem services more prominence in ecosystem management. 


\subsubsection{Ecosystem Service Learning Networks}

Efforts are needed to build the capacity, networks and resources necessary to communicate research more effectively and to improve the understanding of the realities of decision-makers [87]. This requires the establishment of problem-driven learning organizations aimed at facilitating information flows and knowledge sharing, guided by a transdisciplinary approach that nurtures social learning $[8,17,88]$. Convincing commercially-driven landholders that they should engage in such processes is challenging; however, we are seeing some early evidence of this in Eden in the form of an evolving private-public cooperation in restoring regulating services for flood and coastal storm surge mitigation with the insurance sector and water security related work with the food and beverage industry [41,89], as well as in developing guidelines for the game-based tourism industry [90]. Here, using risk as a boundary concept to mainstream ecosystem concerns into business operations seems to have had success and presents opportunities for further research. Additional lessons could be learned from projects, such as the water-fund projects in South America, which link multiple users (e.g., business, local government and land-owners) through investing in conservation activities aimed at ensuring a clean water supply for all [70].

The establishment of an Ecosystem Services forum as part of the South African National Biodiversity Institute's (SANBI) Biodiversity Planning Forum in 2013 will facilitate knowledge exchange and debate concerning the role of ecosystem service science in local and national planning processes. However, in order for the science of ecosystem services to influence cross-sectoral development planning, engagement needs to extend beyond the biodiversity sector and associated ecosystem managers and planning professionals, to those sectors actively altering the state and flow of ecosystem services (e.g., agriculture, mining, infrastructure development). Given the importance of independent consultants in ecosystem management processes, initiating discussions and co-learning opportunities with these stakeholders through the South Africa affiliate of the International Association for Impact Assessment (IAIA) holds promise for the future integration of information on ecosystem services.

\section{Conclusions}

The safeguarding of ecosystem services can only be achieved if they are accounted for in processes that direct ecosystem management. Mainstreaming ecosystem services into policy and decision-making requires an enhanced understanding of a suite of complex decision-making processes across various institutions involved in managing ecosystems. The method developed and applied in this paper allowed us to establish a more in-depth understanding of research-management gaps with regards to ecosystem services and has enabled us to identify key opportunities within ecosystem management processes, where targeted interventions could have the most traction. The method presented in this paper additionally allows for the continued monitoring and evaluation of changes in perceptions and policy related to ecosystem services in the future as stakeholder engagement in the region continues. 


\section{Acknowledgments}

The authors gratefully acknowledge all respondents for their time, openness and willingness to share their knowledge and experience. The National Research Foundation (NRF), the South Africa Netherlands Research Programme on Alternatives in Development Research Capacity Initiative (SANPAD RCI), the Council for Scientific and Industrial Research (CSIR), the Project for Ecosystem Services (ProEcoServ), Stellenbosch University (SU) and the Transdisciplinary, Sustainability, Analysis, Modelling and Assessment (TSAMA) Hub are acknowledged for their financial and other support. We also thank the insightful comments and suggestions from two anonymous reviewers.

\section{Author Contributions}

The authors all contributed to the development of the research and of the paper. In particular, Nadia Sitas coordinated the research activities and carried out the interviews and document analysis.

\section{Conflicts of Interest}

The authors declare no conflict of interest.

\section{References}

1. Sachs, J.D. From millennium development goals to sustainable development goals. Lancet 2012, 379, 2206-2211.

2. Griggs, D.; Stafford-Smith, M.; Gaffney, O.; Rockström, J.; Öhman, M.C.; Shyamsundar, P.; Steffen, W.; Glaser, G.; Kanie, N.; Noble, I. Policy: Sustainable development goals for people and planet. Nature 2013, 495, 305-307.

3. Berkes, F.; Folke, C.; Colding, J. Linking Social and Ecological Systems: Management Practices and Social Mechanisms for Building Resilience; Cambridge University Press: Cambridge, UK, 1998.

4. Folke, C.; Carpenter, S.; Elmqvist, T.; Gunderson, L.; Holling, C.S.; Walker, B. Resilience and sustainable development: Building adaptive capacity in a world of transformations. AMBIO 2002, 31, 437-440.

5. Folke, C.; Jansson, Å.; Rockström, J.; Olsson, P.; Carpenter, S.R.; Chapin, F.S.; Crépin, A.-S.; Daily, G.; Danell, K.; Ebbesson, J.; et al. Reconnecting to the biosphere. AMBIO 2011, 40, 719-738.

6. Kerr, R.A. Time to adapt to a warming world, but where's the science? Science 2011, 334, 1052-1053.

7. Knight, A.T.; Cowling, R.M.; Rouget, M.; Balmford, A.; Lombard, A.T.; Campbell, B.M. Knowing but not doing: Selecting priority conservation areas and the research-implementation gap. Conserv. Biol. 2008, 22, 610-617.

8. O'Farrell, P.J.; Anderson, P.M. Sustainable multifunctional landscapes: A review to implementation. Curr. Opin. Environ. Sustain. 2010, 2, 59-65.

9. Shanley, P.; López, C. Out of the loop: Why research rarely reaches policy makers and the public and what can be done. Biotropica 2009, 41, 535-544.

10. Millennium Ecosystem Assessment. Ecosystems and Human Well-Being: Synthesis; Millennium Ecosystem Assessment and World Resources Institute: Washington, DC, USA, 2005. 
11. Jax, K.; Barton, D.N.; Chan, K.; de Groot, R.; Doyle, U.; Eser, U.; Görg, C.; Gómez-Baggethun, E.; Griewald, Y.; Haber, W. Ecosystem services and ethics. Ecol. Econ. 2013, 93, 260-268.

12. Luck, G.W.; Chan, K.M.; Eser, U.; Gómez-Baggethun, E.; Matzdorf, B.; Norton, B.; Potschin, M.B. Ethical considerations in on-ground applications of the ecosystem services concept. BioScience 2012, 62, 1020-1029.

13. Nahlik, A.M.; Kentula, M.E.; Fennessy, M.S.; Landers, D.H. Where is the consensus? A proposed foundation for moving ecosystem service concepts into practice. Ecol. Econ. 2012, 77, 27-35.

14. Sitas, N.; Prozesky, H.E.; Esler, K.J.; Reyers, B. Opportunities and challenges for mainstreaming ecosystem services in development planning: Perspectives from a landscape level. Landsc. Ecol. 2013, doi:10.1007/s10980-013-9952-3.

15. Schröter, M.; Zanden, E.H.; Oudenhoven, A.P.; Remme, R.P.; Serna-Chavez, H.M.; Groot, R.S.; Opdam, P. Ecosystem services as a contested concept: A synthesis of critique and counter-arguments. Conserv. Lett. 2014, doi:10.1111/conl.12091.

16. Fazey, I.; Evely, A.C.; Reed, M.S.; Stringer, L.C.; Kruijsen, J.; White, P.C.; Newsham, A.; Jin, L.; Cortazzi, M.; Phillipson, J. Knowledge exchange: A review and research agenda for environmental management. Environ. Conserv. 2013, 40, 19-36.

17. Cowling, R.M.; Egoh, B.; Knight, A.T.; O’Farrell, P.J.; Reyers, B.; Rouget, M.; Roux, D.J.; Welz, A.; Wilhelm-Rechman, A. An operational model for mainstreaming ecosystem services for implementation. Proc. Natl. Acad. Sci. USA 2008, 105, 9483-9488.

18. Esler, K.J.; Prozesky, H.; Sharma, G.P.; McGeoch, M. How wide is the "knowing-doing" gap in invasion biology? Biol. Invasions 2010, 12, 4065-4075.

19. Lauber, T.B.; Stedman, R.C.; Decker, D.J.; Knuth, B.A. Linking knowledge to action in collaborative conservation. Conserv. Biol. 2011, 25, 1186-1194.

20. Cash, D.; Clark, W.; Alcock, F.; Dickson, N.; Eckley, N.; Jäger, J. Salience, Credibility, Legitimacy and Boundaries: Linking Research, Assessment and Decision Making; John F. Kennedy School of Government, Harvard University: Boston, MA, USA, 2002.

21. Prager, K.; Reed, M.; Scott, A. Encouraging collaboration for the provision of ecosystem services at a landscape scale_-Rethinking agri-environmental payments. Land Use Policy 2012, 29, 244-249.

22. Reed, M.S.; Hubacek, K.; Bonn, A.; Burt, T.P.; Holden, J.; Stringer, L.C.; Beharry-Borg, N.; Buckmaster, S.; Chapman, D.; Chapman, P.J. Anticipating and managing future trade-offs and complementarities between ecosystem services. Ecol. Soc. 2013, doi:10.5751/ES-04924-180105.

23. Reed, M.S.; Buenemann, M.; Athopheng, J.; Akhtar-Schuster, M.; Bachmann, F.; Bastin, G.; Bigas, H.; Chanda, R.; Dougill, A.; Essahli, W. Cross-scale monitoring and assessment of land degradation and sustainable land management: A methodological framework for knowledge management. Land Degrad. Dev. 2011, 22, 261-271.

24. Evely, A.C.; Pinard, M.; Reed, M.S.; Fazey, I. High levels of participation in conservation projects enhance learning. Conserv. Lett. 2011, 4, 116-126.

25. Lang, D.J.; Wiek, A.; Bergmann, M.; Stauffacher, M.; Martens, P.; Moll, P.; Swilling, M.; Thomas, C.J. Transdisciplinary research in sustainability science: Practice, principles, and challenges. Sustain. Sci. 2012, 7, 25-43. 
26. Favretto, N.; Stringer, L.C.; Dougill, A.J.; Perkins, J.S.; Atlhopheng, J.R.; Reed, M.S.; Thomas, A.; Mulale, K. Time-Series Analysis of Policies and Market Prices for Provisioning Ecosystem Services in Botswana's Kalahari Rangelands; Economics of Land Degradation Initiative: Leeds, UK, 2014.

27. Granek, E.F.; Polasky, S.; Kappel, C.V.; Reed, D.J.; Stoms, D.M.; Koch, E.W.; Kennedy, C.J.; Cramer, L.A.; Hacker, S.D.; Barbier, E.B. Ecosystem services as a common language for coastal ecosystem-based management. Conserv. Biol. 2010, 24, 207-216.

28. Quick, T.; Reed, M.S.; Smyth, M.; Birnie, D.; Bain, C.; Rowcroft, P. Developing Place-Based Approaches for Payments for Ecosystem Services; DEFRA: London, UK, 2013.

29. World Resources Institute. Banking on Nature's Assets: How Multilateral Development Banks Can Strengthen Development by Using Ecosystem Services; World Resources Institute: Washington, DC, USA, 2009.

30. Deutsche Gesellschaft für Internationale Zusammenarbeit (GIZ). Integrating Ecosystem Services into Development Planning: A Stepwise Approach for Practitioners Based on the TEEB Approach; Deutsche Gesellschaft für Internationale Zusammenarbeit (GIZ): Bonn, Germany, 2012.

31. National Planning Commission. The national planning commission. Available online: http://www.npconline.co.za/ (accessed on 28 April 2014).

32. Raymond, C.M.; Fazey, I.; Reed, M.S.; Stringer, L.C.; Robinson, G.M.; Evely, A.C. Integrating local and scientific knowledge for environmental management. J. Environ. Manag. 2010, 91, 1766-1777.

33. Kenter, J.O.; Hyde, T.; Christie, M.; Fazey, I. The importance of deliberation in valuing ecosystem services in developing countries-Evidence from the solomon islands. Glob. Environ. Chang. 2011, 21, 505-521.

34. Knight, A.T.; Sarkar, S.; Smith, R.J.; Strange, N.; Wilson, K.A. Engage the hodgepodge: Management factors are essential when prioritizing areas for restoration and conservation action. Divers. Distrib. 2011, 17, 1234-1238.

35. O’Brien, K.; Reams, J.; Caspari, A.; Dugmore, A.; Faghihimani, M.; Fazey, I.; Hackmann, H.; Manuel-Navarrete, D.; Marks, J.; Miller, R. You say you want a revolution? Transforming education and capacity building in response to global change. Environ. Sci. Policy 2013, 28, 48-59.

36. Yin, R.K. Case Study Research: Design and Methods; Sage: Thousand Oaks, CA, USA, 2003; Volume 5.

37. Eden District Municipality. Eden District Municipality State of the Environment Report; Arcus Gibb: Eden, South Africa, 2008.

38. Biggs, R.; Bohensky, E.; Fabricius, C.; Lynam, T.; Misselhorn, A.; Musvoto, C.; Mutale, M.; Reyers, B.; Scholes, R.J.; Shikongo, S.; et al. Nature Supporting People: The Southern African Millennium Ecosystem Assessment; CSIR: Pretoria, South Africa, 2004.

39. Cowling, R.; Pressey, R.; Rouget, M.; Lombard, A. A conservation plan for a global biodiversity hotspot-The Cape Floristic Region, South Africa. Biol. Conserv. 2003, 112, 191-216.

40. Le Maitre, D.C.; O'Farrell, P.J.; Reyers, B. Ecosystems services in South Africa: A research theme that can engage environmental, economic and social scientists in the development of sustainability science? S. Afr. J. Sci. 2007, 103, 367-376.

41. Nel, J.; le Maitre, D.C.; Forsyth, G.; Theron, A.; Archibald, S. Understanding the Implications of Global Change for the Insurance Industry: The Eden Case Study; CSIR: Stellenbosch, South Africa, 2011. 
42. Reyers, B.; O’Farrell, P.J.; Cowling, R.M.; Egoh, B.N.; le Maitre, D.C.; Vlok, J.H.J. Ecosystem services, land-cover change, and stakeholders: Finding a sustainable foothold for a semiarid biodiversity hotspot. Ecol. Soc. 2009, 14, 38.

43. O'Farrell, P.J.; le Maitre, D.C.; Gelderblom, C.; Bonora, D.; Hoffman, T.; Reyers, B. Applying a resilience framework in the pursuit of sustainable land-use development in the little karoo, south africa. In Advancing Sustainability Science in South Africa; Burns, M., Weaver, A., Eds.; Sun Press: Stellenbosch, South Africa, 2008; pp. 383-430.

44. Maxwell, J.A. Qualitative Research Design: An Interactive Approach, 2nd ed.; Sage: Thousand Oaks, CA, USA, 2005.

45. Eden District Municipality. Eden Growth and Development Strategy; Eden District Municipality: George, South Africa, 2007.

46. Eden District Municipality. Integrated Development Plan for Eden; Eden District Municipality: George, South Africa, 2011/2012.

47. Reyers, B.; Roux, D.J.; O’Farrell, P.J. Can ecosystem services lead ecology on a transdisciplinary pathway? Environ. Conserv. 2010, 37, 501-511.

48. Strydom, H.A.; King, N. Fuggle \& Rabies Environmental Management in South Africa, 2nd ed.; Juta: Cape Town, South Africa, 2009.

49. Babbie, E.; Mouton, J. The Practice of Social Research; Oxford University Press: Cape Town, South Africa, 2001.

50. Daily, G.C. Nature's Services: Societal Dependence on Natural Ecosystems; Island Press: Washington, DC, USA, 1997.

51. Gómez-Baggethun, E.; de Groot, R.; Lomas, P.L.; Montes, C. The history of ecosystem services in economic theory and practice: From early notions to markets and payment schemes. Ecol. Econ. 2010, 69, 1209-1218.

52. Egoh, B.; Rouget, M.; Reyers, B.; Knight, A.T.; Cowling, R.M.; van Jaarsveld, A.S.; Welz, A. Integrating ecosystem services into conservation assessments: A review. Ecol. Econ. 2007, 63, 714-721.

53. Haines-Young, R.; Potschin, M. The links between biodiversity, ecosystem services and human well-being. In Ecosystem Ecology: A New Synthesis; Raffaelli, D., Frid, C., Eds.; Bes Ecological Reviews Series; Cambridge University Press: Cambridge, UK, 2010.

54. TEEB. The Economics of Ecosystems and Biodiversity: Mainstreaming the Economics of Nature: A Synthesis of the Approach, Conclusions and Recommendations of TEEB; TEEB: Geneva, Switzerland, 2010.

55. Bradshaw, G.A.; Borchers, J.G. Uncertainty as information: Narrowing the science-policy gap. Conserv. Ecol. 2000, 4, 7.

56. Reyers, B.; Roux, D.J.; Cowling, R.M.; Ginsburg, A.E.; Nel, J.L.; O’Farrell, P. Conservation planning as a transdisciplinary process. Conserv. Biol. 2010, 24, 957-965.

57. Knight, A.T.; Driver, A.; Cowling, R.M.; Maze, K.; Desmet, P.G.; Lombard, A.T.; Rouget, M.; Botha, M.A.; Boshoff, A.F.; Castley, J. Designing systematic conservation assessments that promote effective implementation: Best practice from South Africa. Conserv. Biol. 2006, 20, 739-750. 
58. Le Maitre, D.; O’Farrel, P.O.; Milton, S.; Atkinson, D.; de Lange, W.; Egoh, B.; Reyers, B.; Colvin, C.; Maherry, A.; Blignaut, J. Assessment and Evaluation of Ecosystem Services in the Succulent Karoo Biome; Council for Scientific and Industrial Research: Stellenbosch, South Africa, 2009.

59. Reyers, B.; Polasky, S.; Tallis, H.; Mooney, H.A.; Larigauderie, A. Finding common ground for biodiversity and ecosystem services. BioScience 2012, 62, 503-507.

60. Emerton, L.; Bos, E. Value: Counting Ecosystems as Water Infrastructure; IUCN: Gland, Switzerland, 2004.

61. Sathirathai, S.; Barbier, E.B. Valuing mangrove conservation in southern thailand. Contemp. Econ. Policy 2001, 19, 109-122.

62. Sudmeier-Rieux, K.; Masundire, H.; Rizvi, A.; Rietbergen, S. Ecosystems, Livelihoods, and Disasters: An Integrated Approach to Disaster Risk Management; IUCN: Gland, Switzerland, 2006.

63. Goldman, R.L.; Tallis, H. A critical analysis of ecosystem services as a tool in conservation projects: The possible perils, the promises, and the partnerships. Ann. N. Y. Acad. Sci. 2009, 1162, 63-78.

64. Lele, S.; Springate-Baginski, O.; Lakerveld, R.; Deb, D.; Dash, P. Ecosystem services: Origins, contributions, pitfalls and alternatives. Conserv. Soc. 2013, 11, 343-358.

65. Norgaard, R.B. Ecosystem services: From eye-opening metaphor to complexity blinder. Ecol. Econ. 2010, 69, 1219-1227.

66. Redford, K.H.; Adams, W.M. Payment for ecosystem services and the challenge of saving nature. Conserv. Biol. 2009, 23, 785-787.

67. Pasquini, L.; Cowling, R.M.; Ziervogel, G. Facing the heat: Barriers to mainstreaming climate change adaptation in local government in the Western Cape Province, South Africa. Habitat Int. 2013, 40, 225-232.

68. Smith, R.; Muir, R.D.; Walpole, M.J.; Balmford, A.; Leader-Williams, N. Governance and the loss of biodiversity. Nature 2003, 426, 67-70.

69. UNEP FI. Insurance in a Changing Risk Landscape; UNEP FI: Geneva, Switzerland, 2012.

70. GIZ; DEA; SALGA; CoGTA. Let's Respond: A Guide to Integrating Climate Change Risks and Opportunities into Municipal Planning; DEA, SALGA, CoGTA: Pretoria, South Africa, 2012.

71. Cundill, G.; Fabricius, C. Adaptive co-management under resource-poor conditions. In Exploring Sustainability Science: A Southern African Perspective; Burns, M., Weaver, A., Eds.; Sun Press: Stellenbosch, South Africa, 2008; pp. 537-568.

72. Daily, G.C.; Polasky, S.; Goldstein, J.; Kareiva, P.M.; Mooney, H.A.; Pejchar, L.; Ricketts, T.H.; Salzman, J.; Shallenberger, R. Ecosystem services in decision making: Time to deliver. Front. Ecol. Environ. 2009, 7, 21-28.

73. WRI. Ecosystem Services: A Guide for Decision Makers; World Resources Institute: Washington, DC, USA, 2010.

74. Smith, S.; Rowcroft, P.; Everard, M.; Couldrick, L.; Reed, M.; Rogers, H.; Quick, T.; Eves, C.; White, C. Payments for Ecosystem Services: A Best Practice Guide; Defra: London, UK, 2013.

75. Primmer, E.; Furman, E. Operationalising ecosystem service approaches for governance: Do measuring, mapping and valuing integrate sector-specific knowledge systems? Ecosyst. Serv. 2012, 1, 85-92. 
76. Brandt, P.; Ernst, A.; Gralla, F.; Luederitz, C.; Lang, D.J.; Newig, J.; Reinert, F.; Abson, D.J.; von Wehrden, H. A review of transdisciplinary research in sustainability science. Ecol. Econ. 2013, 92, 1-15.

77. SAPECS. Southern African Programme for Ecosystem Change and Society. Available online: www.sapecs.org (accessed on 27 May 2014).

78. TSAMA Hub. Transdisicplinary, Sustainability, Analysis, Modelling and Assessment HUB. Available online: wwwtsama.org.za (accessed on 27 May 2014).

79. Hadorn, G.H.; Hoffmann-Riem, H.; Biber-Klemm, S.; Grossenbacher-Mansuy, W.; Joye, D.; Pohl, C.; Wiesmann, U.; Zemp, E. Handbook of Transdisciplinary Research; Springer: Bern, Switzerland, 2008.

80. Sowman, M.; Brown, A.L. Mainstreaming environmental sustainability into South Africa's integrated development planning process. J. Environ. Plan. Manag. 2006, 49, 695-712.

81. ProEcoServ. The Project for Ecosystem Services. Available online: http://www.proecoserv.org (accessed on 2 April 2014).

82. Blignaut, J.N.; de Wit, M.; Esler, K.J.; le Maitre, D.C.; Milton, S.; Mitchell, S.; van der Elst, L. Restoration in South Africa. Quest 2010, 6, 26-30.

83. FEWLE. The Food Energy, Water, Land and the Environment Nexus. Available online: http://acdi.uct.ac.za/research/fewle (accessed on 2 April 2014).

84. Burr, V. An Introduction to Social Constructionism; Routledge: Hove, UK, 2003.

85. Raymond, C.M.; Singh, G.G.; Benessaiah, K.; Bernhardt, J.R.; Levine, J.; Nelson, H.; Turner, N.J.; Norton, B.; Tam, J.; Chan, K.M. Ecosystem services and beyond: Using multiple metaphors to understand human-environment relationships. BioScience 2013, 63, 536-546.

86. Vromans, D.C.; Maree, K.S.; Holness, S.; Job, N.; Brown, A.E. The Garden Route Biodiversity Sector Plan for the George, Knysna and Bitou Municipalities: Supporting Land-Use Planning and Decision Making in Critical Biodiversity Areas and Ecological Support Areas for Sustainable Development; Garden Route Initiative and South African National Parks: Knysna, South Africa, 2010.

87. Roux, D.J.; Rogers, K.H.; Biggs, H.; Ashton, P.J.; Sergeant, A. Bridging the science-management divide: Moving from unidirectional knowledge transfer to knowledge interfacing and sharing. Ecol. Soc. 2006, 11, 4.

88. Cundill, G.; Cumming, G.; Biggs, D.; Fabricius, C. Soft systems thinking and social learning for adaptive management. Conserv. Biol. 2012, 26, 13-20.

89. World Wildlife Fund South Africa. Managing Water Risk: Business Response to the Risk of Climate Change in South Africa-A Synthesis; WWF South Africa: Cape Town, South Africa, 2011; p. 22.

90. Forsyth, G.; Vlok, J.H.J.; Reyers, B. Retention and Restoration of the Biodiversity of the Little Karoo; CSIR: Stellenbosch, South Africa, 2008.

(C) 2014 by the authors; licensee MDPI, Basel, Switzerland. This article is an open access article distributed under the terms and conditions of the Creative Commons Attribution license (http://creativecommons.org/licenses/by/3.0/). 